\title{
Priznanje Republike Hrvatske od Svete Stolice u hrvatskoj memoaristici
}

\author{
Uz 30. obljetnicu međunarodnog priznanja Republike Hrvatske
}

Hrvoje Lončarević*

\begin{abstract}
Sažetak
Ovaj rad prikazuje kako je priznanje Republike Hrvatske od strane Svete Stolice $i$ uspostava diplomatskih odnosa predstavljeno u hrvatskoj knjižnoj memoaristici. Uvodno su izneseni opći podatci o odnosu izmedu Hrvata i Svete Stolice, o diplomaciji Svete Stolice, a u središnjem dijelu rada povijesni kontekst međunarodnoga priznanja, s posebnim osvrtom na svjedočanstva posljednjega veleposlanika Jugoslavije pri Svetoj Stolici Ivice Maštruka i prvoga veleposlanika Republike Hrvatske Ive Livljanića. Autor zaključuje da je Sveta Stolica u okolnostima raspleta jugoslavenske krize iskazala veliko umijeće diplomatskoga usmjeravanja $i$ vođenja političkih postupaka te dala ključan doprinos međunarodnomu priznanju Republike Hrvatske.
\end{abstract}

Ključne riječi: Sveta Stolica; Republika Hrvatska; priznanje; diplomacija; memoari

\section{Uvod}

Ured za tisak Svete Stolice 13. siječnja 1992. objavio je priopćenje o priznanju Republike Hrvatske i Republike Slovenije. U diplomatskoj noti na francuskom jeziku br. 225/92/RS od 13. siječnja 1992. Državno tajništvo navelo je da ima čast priopćiti kako Sveta Stolica priznaje suverenost i neovisnost Republike Hrvatske. ${ }^{1}$ Bila je to gaudium magnum — velika radost — jer je tim činom na osobit i znakovit način, imajući u vidu gotovo četrnaestostoljetni kontinuitet veza između Hrvata i Svete Stolice, započeto ispunjavanje želje mnogih hrvatskih naraštaja o ponovnoj međunarodno priznatoj državnoj neovisnosti i suverenosti.

* Hrvoje Lončarević, mag. kroat., mag. comm., Središnji državni ured za razvoj digitalnog društva. Adresa: Ul. Ivana Lučića 8, 10000 Zagreb, Hrvatska. ORCID iD: https://orcid.org/0000-00033639-7727. E-adresa: hloncarevic@gmail.com

1 »La Secrétairerie d'Etat a l'honneur de communiquer que le Saint-Siège reconnaît la souveraineté et l'indépendance de la République de Croatie« (Čečuk, 2007, 972). 
Odnosi između Hrvata i Svete Stolice sežu u rani srednji vijek. Općenito se smatra kako je za vrijeme pape Ivana IV. (640-642.) započelo pokrštavanje Hrvata, spominje se sporazum Hrvata s papom Agatonom (678-681.), kojim su se obvezali ne napadati zemlje drugih naroda i živjeti u miru sa svima koji to budu željeli, uz zauzvrat trajnu zaštitu pape, odnosno Crkve, a središnje mjesto iz toga razdoblja ima pismo Ivana VIII. knezu Branimiru od 7. lipnja 879., što je bilo razmjerno diplomatskomu priznanju tadašnje hrvatske države (Čečuk, 2007, 984 985; Einaudi, 2003, 34). Nepuno stoljeće poslije papa Ivan X. nazvao je kralja Tomislava "najizvrsnijim sinom Svete Rimske Crkve”, da bi godine 1076. Grgur VII. po svojem poslaniku opatu Gebizonu okrunio Dmitra Zvonimira kraljem Hrvatske i Dalmacije, koji je pak Hrvatsku stavio pod izravnu zaštitu Svete Stolice. Vrijedno je spomenuti i posebnu vezu između Svete Stolice i Dubrovačke Republike, koja je imala poslanika pri Svetoj Stolici, koja se pak služila uslugama Republike kako bi pomagala katolike u krajevima pod turskom vlašću, jer je Dubrovnik imao pristup u te krajeve.

Uspostavom Kraljevine SHS, odnosno Jugoslavije vatikanska diplomacija dolazi "bliže" Hrvatskoj, ali to razdoblje obilježeno je neuspjelim pokušajem konkordata 1935. godine. Tijekom NDH, odnosno do 28. prosinca 1945., kada ga je komunistička vlast proglasila persona non grata, Sveta Stolica imala je u Zagrebu apostolskoga pohoditelja (ne dakle apostolskoga nuncija) Giuseppea Ramira Marconea. Nastojanja da njegov tajnik Giuseppe Masucci u nekom svojstvu ostane u Zagrebu nisu uspjela — povučen je 20. ožujka 1946. godine. Nova jugoslavenska država i Sveta Stolica uspostavili su diplomatske odnose, koji su nakon imenovanja nadbiskupa Stepinca kardinalom bili jednostrano prekinuti s jugoslavenske strane, a nuncij Silvio Oddi protjeran je 17. prosinca 1952. godine. Diplomatski odnosi ponovno su bili uspostavljeni 1970. godine. Ti su odnosi politički imali isključivo jugoslavensko-vatikansku "relaciju", iako su u njima određenu ulogu imali i predstavnici iz "hrvatske kvote" u tadašnjoj jugoslavenskoj diplomaciji. Priznanjem Republike Hrvatske od Svete Stolice Hrvatska je započela novo razdoblje punih međudržavnih odnosa sa Svetom Stolicom (Mlivončić, 1993, 227-229; Einaudi, 2003, 33-37).

Temelj i naglasak ovoga rada na memoarskom je gradivu hrvatskih državnih dužnosnika² i njihovu doživljaju postupka priznanja Republike Hrvatske od Svete Stolice 13. siječnja 1992. te uspostave diplomatskih odnosa između dviju država.

\section{Ciljevi i temeljne vrijednosti diplomacije Svete Stolice}

Sveta ili Apostolska Stolica označava Svetoga Oca, rimskoga biskupa i pastira sveopće (katoličke) Crkve i središnje urede Rimske kurije (Eterović, 2019, 142). Subjekt je međunarodnoga prava kao što je i Država Grada Vatikana (Vatikan-

2 Uloga Svete Stolice i pape Ivana Pavla II. u međunarodnom priznanju Republike Hrvatske predstavljena je člankom na engleskom jeziku: Holjevac Tuković i Holjevac, 2019. 
ski Grad). Ta dva subjekta međunarodnoga prava, Sveta Stolica i Država Grada Vatikana, ujedinjeni su u osobi suverena — rimskoga biskupa (pape). Kako bi se stavila u odnos dva navedena subjekta međunarodnoga prava, može se reći kako Država Grada Vatikana Svetoj Stolici osigurava teritorijalnu suverenost i služi kao prostor za slobodno i neometano djelovanje (Eterović, 2019, 149). Sveta Stolica pak zastupa Državu Grada Vatikana u međunarodnim odnosima, jer je Sveta Stolica u pravnom smislu nositelj vrhovne vlasti, odnosno suveren Države (Miščin, 2006, 166-168). Kao subjekt međunarodnoga prava Sveta Stolica ima diplomatske odnose s državama i međunarodnim ustanovama i organizacijama.

Sveta Stolica u diplomatskom djelovanju polazi od triju temeljnih vrijednosti, sukladno teološkim izvorištima. Prva je katolicitet djelovanja: Katolička je crkva u svojim temeljima univerzalna, sveopća, otvorena svima, u svim vremenima i kulturama. Druga je vrijednost univerzalni humanizam: Crkva vjeruje da je čovjekova sudbina usko povezana s Kristom, jer je u njemu čovještvo (ljudskost) dosegnulo savršenost te svi imaju udio u toj punini dostojanstva čovještva. Treća je temeljna vrijednost neutralnost, koja Svetoj Stolici daje diplomatsku vjerodostojnost i ugrađena je u potpisane bilateralne sporazume (Miščin, 2006, 74-90).

\section{Put Svete Stolice prema priznanju Republike Hrvatske}

\subsection{Uvjeti priznanja}

Na putu prema međunarodnom priznanju Hrvatska je trebala ispuniti određene uvjete međunarodne zajednice. U svojoj knjizi Diplomatska oluja bivši hrvatski ministar vanjskih poslova Mate Granić ističe kako je ključ napretka u tom pogledu bila odluka Badinterove komisije (Granić, 2019, 30-31), koja je zaključila da se bivša država raspala te da bivše federalne republike (države) koje žele mogu tražiti međunarodno priznanje u svojim dotadašnjim granicama. Važan uvjet ispunjen je potpisivanjem sporazuma o deblokadi i evakuaciji vojarni 8 . prosinca 1991. godine. Uvjeti su bili i prihvaćanje Vanceova plana, ${ }^{3}$ prihvaćanje mirovnih snaga UN-a (UNPROFOR), donošenje Ustavnoga zakona o zaštiti manjina te potpisivanje sporazuma o prekidu vatre, što je ostvareno 3. siječnja 1992. u Sarajevu. Posljednji uvjet bilo je pozitivno mišljenje Promatračke misije Europske zajednice. Njihovo negativno mišljenje nije moglo spriječiti priznanje, ali ga je moglo odgoditi na nekoliko mjeseci. ${ }^{4}$

3 Vanceov (američki diplomat Cyrus Vance) plan prijedlog je mirovne operacije UN-a u Hrvatskoj, objavljen u prosincu 1991. godine. Nakon što su ga prihvatile sukobljene strane, u veljači 1992. rezultirao je dolaskom UN-ovih mirovnih snaga u Republiku Hrvatsku i uspostavom područja pod njihovom zaštitom.

4 Okolnosti donošenja takva mišljenja opisuje Mate Granić: »Državni je vrh 27. prosinca u obnovljenim Banskim dvorima tiho i skromno slavio Božić i Novu godinu. Bilo je prisutno 50-ak dužnosnika. Poslije ponoći na proslavu je stigao Ivan Jarnjak, zamjenik ministra unutarnjih poslova i šef specijalne policije, ali i osoba od posebnog povjerenja predsjednika Tuđmana. Kratko je informirao predsjednika, koji je odmah promijenio izraz lica i raspoloženje. Pozvao me i priopćio mi da su 'sladoledari', kako su hrvatski građani kolokvijalno nazivali europske promatrače, dali 


\subsection{Traženje mirnoga rješenja}

\subsubsection{Poticanje otvorenih razgovora $i$ suradnje}

Sveta Stolica nije išla protiv tih uvjeta, nego ih je nastojala što bolje iskoristiti. U tom smislu vatikanska je diplomacija još na sastanku Konferencije za suradnju i sigurnost u Europi (KESS) u Beču 29. siječnja 1991., pozivajući se na Parišku povelju i dokumente KESS-a, izrazila načelno stajalište da nijedan narod ne smije svoju volju nametati drugomu narodu, što, konkretno, pretpostavlja poštovati pravo naroda na samoodređenje i prava osoba, protiviti se uporabi sile u rješavanju spornih pitanja, promicati bez prestanka i neumorno dijalog među zainteresiranim stranama te omogućiti uspostavu mirne koegzistencije među narodima Jugoslavije, u pravdi i međusobnom poštovanju (Eterović, 2019, 144).

Za Hrvatsku, koja se borila s agresijom, to se činilo sporim, suzdržanim i neproduktivnim. Kakvo je u to vrijeme bilo ozračje tijekom prvoga posjeta hrvatskoga državnoga izaslanstva Svetomu Ocu 25. svibnja 1991., opisuje Davorin Rudolf u knjizi Rat koji nismo htjeli: »Pitao sam ga [predsjednika Tuđmana] kako je protekao njegov razgovor tête-à-tête sa Svetim Ocem, koji je trajao dvadesetak minuta. Odgovorio mi je škrto, činilo mi se da nije osobito zadovoljan. Susret s Papinim državnim tajnikom... kardinalom Angelom Sodanom bio je nekako srdačan, a zapravo suzdržan i kurtoazan. Državni tajnik je govorio o strpljenju, ljubavi i razumijevanju. A mi smo očekivali jasnu podršku, stajali napeti, na vršcima prstiju, jer su nas tukli sa svih strana. Nakon toga razgovora nitko od nas nije pretpostavljao da će državni vrh važne i utjecajne Države Grada Vatikana... poslije svega nekoliko mjeseci, u listopadu i studenome 1991., najsnažnije poduprijeti međunarodnopravni subjektivitet Hrvatske« (Rudolf, 1991, 223).

Drugim riječima, Hrvatska je još bila u diplomatskoj blokadi, dok je istodobno rastao vojno-politički pritisak Srbije i srpskoga bloka u saveznim tijelima na Hrvatsku. Stoga je hrvatsko državno vodstvo pomoć Svete Stolice u tom trenutku doživljavalo odlučujućom.

S druge strane, Sveta je Stolica taktizirala, pazeći da ne izazove otvorenu negativnu reakciju vodećih svjetskih država (Gregurić, 1998, 374), odnosno nekih krugova koji su se, osobito preko britanske i francuske diplomacije, ${ }^{5}$ veoma pro-

negativno mišljenje. Tražio je od mene, na Jarnjakov prijedlog, hitnu akciju i dao neke važne savjete koje sam prihvatio. Problem je riješen u tjedan dana te smo Jarnjak i ja s predsjednikom popili pjenušac u njegovu uredu. Europski monitori dali su pozitivno mišljenje « (Granić, 2019, 31).

5 Prema Granićevu svjedočanstvu, kardinal Tauran ispričao mu je 1998. kako je u vremenu prije međunarodnoga priznanja Hrvatske gotovo pet sati razgovarao s francuskim predsjednikom Françoisom Mitterrandom. »Kazao mi je kako je upotrijebio sve svoje talente, argumente i autoritet Svetog Oca da francuskog predsjednika uvjeri u potrebu hitnog međunarodnog priznanja Hrvatske. Nažalost, rezultata nije bilo. Mitterrand je njihov dugi razgovor završio kratkim zaključkom: 'Dragi Jean-Louis, ali Srbi su naši stari prijatelji, posebno od Prvoga svjetskog rata. Ne možemo ih ostaviti same. Ne mogu podržati hitno međunarodno priznanje Hrvatske.' Tauran mi je rekao kako ga je to još više učvrstilo u uvjerenju da je sveti otac Ivan Pavao Drugi u pravu te da su se s još više žara usmjerili na aktivnosti međunarodnog priznanja Hrvatske« (Granić, 2019, 32). 
tivili osamostaljenju Hrvatske (Fuček, 1994, 8-9; Ostojić, 1998). Stoga nije još otvoreno zagovarala njezinu neovisnost. Ipak, Papa je davao signale u tom smislu, primjerice tijekom pastoralnoga posjeta Pečuhu 17. kolovoza 1991., kada je pred okupljenim mnoštvom, u kojem je bilo dvadesetak tisuća Hrvata, znakovito izrazio bliskost njihovim »zakonitim težnjama« za uspostavom samostalne države (Mlivončić, 1993, 124).

\subsubsection{Promicanje međunarodnoga priznanja Hrvatske i Slovenije}

Za Hrvatsku je u tom trenutku bilo korisno što je Sveta Stolica promatrala pitanje njezina osamostaljenja "u paketu" sa Slovenijom jer je time otupljivana oštrina neutemeljenih, no u nekim međunarodnim krugovima prijemčivih srpskih optužaba da se u Hrvatskoj obnavlja NDH i da samostalna Hrvatska ugrožava opstanak Srba u njoj.

Kako bi se Sveta Stolica uvjerila u stanje u Jugoslaviju, tajnik za odnose s državama Jean-Louis Tauran posjetio je Zagreb i Beograd od 5. do 8. kolovoza 1991. (Petrač, 2014, 41), dakle tijekom tromjesečnoga moratorija na ustavnu odluku Hrvatskoga sabora o suverenosti i samostalnosti Republike Hrvatske od 25. lipnja 1991., čije je stupanje na snagu potpisivanjem Brijunske deklaracije 8 . srpnja (bez glasovanja Hrvatskoga sabora o tom) odgođeno na tri mjeseca. Svetoj Stolici nakon tog je posjeta bilo jasno da se jugoslavenska federacija raspada i da se ne može postići konstruktivan dijalog između predstavnika republika. ${ }^{6}$ Zato je krenula pozivati međunarodnu zajednicu, posebice europske države, da pojačaju nastojanje kako bi spriječile krvoproliće. ${ }^{7}$ Da je međunarodno priznanje put k tomu, dao je naslutiti L'Osservatore Romano, koji je nakon druge privatne audijencije (prva je bila 25. svibnja 1991.) predsjednika Tuđmana kod pape Ivana Pavla II. 3. listopada iznio stav da Hrvatska ima pravo na priznanje, što je protumačeno kao stav Svete Stolice.

\subsection{Priznanje Republike Hrvatske}

Sveta Stolica sljedećih se tjedana posvetila postizanju "međunarodne suglasnosti" 8 o priznanju Hrvatske i Slovenije. Bitan korak prema tomu bio je

6 Thomas Patrick Melady, veleposlanik Sjedinjenih Američkih Država pri Svetoj Stolici 1989.1993., piše: »Papa je poslao nadbiskupa Taurana u ratom razdiranu Jugoslaviju u kolovozu 1991. Ubrzo nakon povratka, 13. kolovoza, Tauran je rekao mom zamjeniku Cameronu Humeu, da je 'Jugoslavija nepovratno promijenila oblik'. Sveta Stolica, kazao je, priznaje legitimno pravo Slovenije i Hrvatske da odluče o svojim budućim odnosima s drugim državama« (Melady, 1997, 158).

7 Franjo Gregurić zapisao je kako je Tauran upravo na dan donošenja Deklaracije Europske zajednice o Jugoslaviji (26. kolovoza 1991.) zahtijevao od Hansa van den Broeka, predsjednika Vijeća ministara vanjskih poslova Europske zajednice, da se zaustavi sila i organizira početak političkoga dijaloga između svih republika u Jugoslaviji. Pozvavši se na završni dokument iz Helsinkija, istaknuo je načelo ravnopravnosti naroda i pravo naroda na samoodređenje. Istoga dana Sveti Otac obratio se predsjedniku Predsjedništva SFRJ Stjepanu Mesiću da djeluje u tom smislu (Gregurić, 1998, 374).

8 Izraz consenso internazionale ("međunarodna suglasnost") uporabio je državni tajnik kardinal Angelo Sodano 30. rujna 1991. u razgovoru za njemačke novine Die Welt (Valente, 2011). 
Memorandum zemljama članicama KESS-a, koji je državni tajnik Angelo Sodano 26. studenoga 1991. predao veleposlanicima zemalja članica. Memorandumom Sveta Stolica poziva međunarodnu zajednicu da uzme u razmatranje potrebu poštovanja prava na neovisnost naroda Hrvatske i Slovenije i onih koji se žele koristiti tim pravom. Također, iskazala je uvjerenje da je došao trenutak za međunarodno priznanje Hrvatske i Slovenije prije Božića (Eterović, 2019, 148-149). Američki veleposlanik pri Svetoj Stolici Melady, koji je bio nazočan, o tom piše: »Predao nam je memorandum kojim se pozivaju naše vlade da priznaju Sloveniju i Hrvatsku 'u roku od mjesec dana'. [...] Bilo je to prvi put u modernoj povijesti da je Sveta Stolica djelatno vodila kampanju za priznavanje novih država« (Melady, 1997, 159). Učinak je ubrzo bio vidljiv. Već su se 16. prosinca 1991. u Bruxellesu ministri vanjskih poslova država Europske zajednice dogovorili o postupku priznanja svih jugoslavenskih republika koje to formalno zatraže i ispune za to određene uvjete. U Službenoj izjavi 20. prosinca 1991. Sveta Stolica pozdravila je i poduprla to stajalište te je najavila da će potvrdno odgovoriti na zahtjeve Hrvatske i Slovenije i priznati njihovu nezavisnost. Valja napomenuti kako je Sveta Stolica postavila i uvjet za priznanje koji nisu tražile države Europske zajednice, naime prihvaćanje nadzora poštovanja prava nacionalnih manjina, koji je trebalo obavljati Povjerenstvo visokih djelatnika KESS-a (Eterović, 2019, 153). ${ }^{9}$

\subsection{1. Čin priznanja}

Sveta Stolica poslala je dakle Hrvatskoj i Sloveniji uvjete za priznanje njihove neovisnosti, na koje je trebalo odgovoriti do 23. prosinca. Predstavnici dviju republika brzo su odgovorili potvrdno, a slične su obveze prihvaćene i od država Europske zajednice. Nije više trebalo otezati. Sveta Stolica priznala je Republiku Hrvatsku (i Sloveniju) 13. siječnja 1992. Zemlje Europske zajednice priznale su obje republike dva dana nakon toga, 15. siječnja. Sveta Stolica u svojoj je Izjavi još 20. prosinca 1991., a zatim ponovno 13. siječnja 1992. istaknula da želi zadržati i unaprijediti odnose sa svim zemljama bivše Jugoslavije, pa stoga diplomatski odnosi Svete Stolice i Beograda nikada nisu bili prekinuti, iako je dio srpske promidžbe stavljao Svetu Stolicu na stranu zemalja koje prijete opstanku Jugoslavije (Eterović, 2019, 154). Srpska je promidžba naime nastojala na svaki način spriječiti priznanje, pri čemu je djelovanje Svete Stolice javno napadala kao »zavjereničko« protiv Jugoslavije i srpskoga naroda, čineći sve kako bi politiku »Vatikana« predstavila kao otvorenu potporu stvaranju »druge $\mathrm{NDH}$ «.

Nedvojbeno je Sveta Stolica priznanjem 13. siječnja učinila presedan. Možemo navesti najmanje tri razloga tomu: prvo, htjela je dati snažan poticaj i drugim državama koje se bile spremne na taj korak ili su ga još procjenjivale. Drugo, željela je istaknuti posebnost svojega čina, u svjetlu stava da kao božanska univerzalna (katolička) nije ograničena na prolazne političke interese. Treći je osobna naklonost Ivana Pavla II. prema Hrvatskoj i Hrvatima. O tom je i prvi predsjed-

9 Valja naglasiti kako Sveta Stolica, govoreći o nacionalnim manjinama, ne spominje samo njihova prava, nego i dužnosti, što se ne spominje u javnom diskursu. 
nik Franjo Tuđman u intervjuu za List MI potkraj siječnja 1992. rekao: »Ako je Ivan VIII. za Hrvatsku u njezinim početcima važan za ustanovljenje Hrvatske u europskoj povijesti, u okviru Katoličke crkve uloga Ivana Pavla II. je tolika da se uopće ne može izraziti njezina važnost «(Petrač i Šanjek, 1995, 22). Dakako, priznanje nije bilo tek dar Svete Stolice bez uzvratnoga očekivanja, prije svega da Hrvatska bude protagonist uspostave mira, što je Ivan Pavao II. naglasio prigodom prvoga posjeta Hrvatskoj 1994. godine.

\section{Dvojica veleposlanika}

Ukratko iznijevši događaje vezane za pripremu i čin priznanja Republike Hrvatske od Svete Stolice, u daljnjem tekstu osvrnuti nam se na sjećanja dvojice veleposlanika u tom razdoblju. Riječ je o posljednjem veleposlaniku Socijalističke Federativne Republike Jugoslavije pri Svetoj Stolici Ivici Maštruku i prvom veleposlaniku Republike Hrvatske Ivi Livljaniću. Pri tom treba uzeti u obzir da memoari nastaju post factum, pa ih, zbog moguće promjenjivosti sjećanja, a i možebitne određene "prilagodbe" suvremenosti i budućnosti, treba primati cum grano salis. Ipak, oni su dragocjen prinos historiografiji, prije svega zbog opisa ukupnoga ozračja pojedinih povijesnih događaja ili procesa i iznošenja podataka nezapisanih u drugim dokumentima.

\subsection{Ivica Maštruko — veleposlanik države koja ne postoji}

U knjizi Sveta Stolica A. D. 1991.: Aambasador zemlje koje nema Ivica Maštruko, koji je bio jugoslavenski veleposlanik pri Svetoj Stolici od godine 1989. do 8. siječnja 1992., navodi četiri bitna nadnevka: 8. studenoga 1991., kada međunarodna zajednica mijenja svoj pogled spram događaja u Jugoslaviji; 26. studenoga 1991., kada su državni tajnik Svete Stolice Angelo Sodano i tajnik za odnose s državama Jean-Louis Tauran pozvali veleposlanike zemalja KESS-a akreditirane pri Sv. Stolici i predali im Memorandum; 20. prosinca 1991., kada je u 13 sati u Državnom tajništvu veleposlaniku Maštruku predana Izjava Svete Stolice o prihvaćanju zahtjeva Hrvatske i Slovenije za priznanje neovisnosti te 13. siječnja 1992., dan objave priznanja (Maštruko, 2012, 215-229).

\subsubsection{Memorandum Svete Stolice i najava priznanja}

Posebno važnim Maštruko smatra 26. studenoga, koji on naziva presudnim za međunarodno priznanje Hrvatske: predaja Memoranduma veleposlanicima zemalja KESS-a: »Bio je to — i prema mojoj tadašnjoj i prema mojoj naknadnoj ocjeni i pameti - odlučujući datum za početak stvarnog procesa donošenja odluke o međunarodnom priznanju hrvatske i slovenske samostalnosti. [...] Toga sam dana telefonski dobio poziv za hitan sastanak u ranovečernjim (ili kasno poslijepodnevnim) satima u Državnom tajništvu Svete Stolice. Rečeno mi je da budem tamo u 18 sati. [...] Za vatikanske uzuse bilo je to neobično vrijeme i bio je to neobičan način za sazivanje sastanka te vrste. Prigodom ulaska u dvoranu 
za sastanke uručen nam je odmah Memorandum Svete Stolice za države učesnice KESS-a napisan na tri stranice (sa zaglavljem Sekcije za odnose s državama Svete Stolice). [...] Memorandum smo pročitali u tišini, a zatim je kardinal Sodano kratko iznio uvodne napomene i naglasio da se ova inicijativa provodi na poticaj pape Ivana Pavla II, te da bi vlade zemalja KESS-a još jednom trebale preispitati svoju strategiju u odnosu na zbivanja u Jugoslaviji. Rekao je, također, da je svjestan da se priznanjem samostalnosti Hrvatske i Slovenije ne rješavaju svi problemi, ali da je to ključ za početak stvaranja novih odnosa na kontinentu i važno međunarodno oruđe za pomoć Hrvatskoj i Sloveniji da mogu pregovarati s drugačijih pozicija. Nadbiskup Tauran je duže govorio i, između ostalog, rekao da se međunarodna zajednica mora opredijeliti protiv agresije, te da Sveta Stolica, ovom inicijativom, preuzima svoj dio odgovornosti i želi da što veći broj država prihvati njen prijedlog. Ako se to ne dogodi — rekao je Tauran — tada će Sveta Stolica biti među onim manjim brojem zemalja koje će priznati Hrvatsku i Sloveniju. [...] Od nas prisutnih zatraženo je da poštujemo diskreciju i da javno ne iznosimo sadržaj Memoranduma, te da zamolimo svoje vlade da u roku od desetak dana dostave svoje stavove o prihvaćanju ili odbijanju vatikanske inicijative, kako bi se - na osnovi tih podataka - mogla donijeti odluka o daljnjim koracima. Moram reći da je nekoliko veleposlanika već na ovom sastanku izrazilo rezervu prema inicijativi Svete Stolice. Riječ je o ambasadorima nama vrlo bliskih i prijateljskih zemalja« (Maštruko, 2012, 221).

\subsubsection{Presedan Svete Stolice}

Treći važan nadnevak bio je 20. prosinca, kada je u 13 sati spomenuta Izjava Svete Stolice predana veleposlaniku Maštruku u Državnom tajništvu: »20. prosinca u 13 sati, u Državnom tajništvu uručena mi je Izjava Svete Stolice koja je značila prihvaćanje zahtjeva Hrvatske i Slovenije za priznavanje nezavisnosti. [...] A što se, pak, toga tempa tiče u Državnom tajništvu izrazili su zadovoljstvo pristiglim informacijama o stavovima pojedinih zemalja u vezi s priznavanjem Hrvatske i Slovenije « (Maštruko, 2012, 224). To je zapažanje važno jer upućuje na zaključak da je Sveta Stolica već privolila "kritičnu masu" država za priznanje Hrvatske i Slovenije, što objašnjava razlog sastavljanja Izjave i njezine predaje tada još jugoslavenskomu veleposlaniku Maštruku.

Dan priznanja Republike Hrvatske 13. siječnja 1992. i događaji vezani uz taj čin Maštruko slikovito opisuje u svojem stilu: »I došao je taj 13. siječnja. Bio je to za mene zadnji dan kada sam još mogao ući u svoj sada već bivši ured u mojoj sada već bivšoj ambasadi. Rješenjem beogradskog ministarstva morao sam se u potpunosti razdužiti (financijski i materijalno) tek sutradan. Otišao sam, dakle, ujutro u kancelariju nešto fotokopirati i pjevušeći namjeravao otići u nepovrat. Zazvoni mi 'celulare' (tako su u počecima tepali prvim mobitelima, a zvali su ih još i 'telefonino') i javlja se moja supruga, pa će sva ushićena: 'Javio mi se sada Eterović i kaže da je Sveta Stolica formalno i službeno priznala Hrvatsku.' Rekoh joj da nisam baš siguran da li je na telefonu bio Eterović, jer tih je dana bilo raznih provokacija i podvaljivanja lažnih vijesti. Jednu je takvu obavijest neoprezno 
prihvatio i Ured predsjednika Tuđmana. Zato sam odmah uzvratio poziv monsinjoru Eteroviću, tadašnjem savjetniku u Državnom tajništvu (kasnije nunciju u Ukrajini i danas visokom dužnosniku u vatikanskoj Kuriji). Želio sam provjeriti vijest i želio sam njegovu osobnu potvrdu telefonskog poziva mojoj supruzi. 'Točno je', reče mi uvaženi moj ‘bodulski kompanjon' Eterović, ‘odluka je donesena i bit će emitirana danas u 12,30 preko Radio Vatikana.' Otišao sam po priopćenje u Ured za tisak Svete Stolice, javio odmah Uredu predsjednika i ministarstvu u Zagrebu. Ne vjeruju ni oni u potpunosti i traže da još jednom provjerim. Rekoh im da ce i oni danas dobiti oficijelnu notu, jer je vladama Slovenije i Hrvatske ta nota već upućena. Faxom im šaljem i tekst Priopćenja. [...] I tako je Hrvatska međunarodno priznata (Maštruko, 2012, 227-229).

\subsection{Ive Livljanić - prvi veleposlanik Republike Hrvatske pri Svetoj Stolici}

O tim povijesnim danima piše i prvi veleposlanik Republike Hrvatske pri Svetoj Stolici Ive Livljanić. Dio se tiče nadnevaka koje smo spomenuli. Ono što je novo tiče se prije svega uspostave diplomatskih odnosa Svete Stolice s Republikom Hrvatskom i predaje vjerodajnica poglavarima država, predsjedniku Franji Tuđmanu i papi Ivanu Pavlu II.

\subsubsection{Apeli Svete Stolice za mir}

Budući da nije bio neposredni svjedok događaja u Vatikanu 1991., Livljanić upućuje na spomenuti kontekst uoči priznanja, pozivajući se prije svega na knjigu dokumenata koju je objavila Sveta Stolica La crisi jugoslava, posizione e azione della Santa Sede, 1991-1992 (Quaderni de L'Osservatore romano, 1992.) i na obavijesti koje je dobivao iz raznih izvora. Vezano uz dane koji su prethodili priznanju 13. siječnja 1992., i Livljanić ističe 26. studenoga 1991. kao ključan, upravo presudan nadnevak (Livljanić, 2017, 87).

\subsubsection{Uspostava diplomatskih odnosa između Svete Stolice i Republike Hrvatske}

Ocjenjujući ulogu Svete Stolice u međunarodnom priznanju Hrvatske i uspostavu diplomatskih odnosa nakon priznanja, što se dogodilo 8. veljače, Livljanić naglašava da je to bilo za vatikanske pojmove neuobičajeno brzo. Razmijenjene su vjerodajnice, slijedilo je imenovanje nuncija 29. veljače te Livljanićevo imenovanje veleposlanikom 11. ožujka. Vrhunac u uspostavljanju diplomatskih odnosa svakako su nadnevci 11. svibnja, kada je nuncij Einaudi predao vjerodajnice predsjedniku Tuđmanu, i 3. srpnja, kada ih je Livljanić predao Ivanu Pavlu II. Koliko je za nj osobno, a i za hrvatski narod, značilo priznanje, Livljanić je iskazao u govoru na konferenciji održanoj povodom 20. obljetnice uspostave diplomatskih odnosa između Svete Stolice i Republike Hrvatske 29. listopada 2012. u Gradu Vatikanu: »Dan 3. srpnja 1992. bez sumnje je najvažniji i najuzbudljiviji trenutak ne samo moje diplomatske karijere, nego općenito mojeg života — predavanje vjerodajnica papi Ivanu Pavlu II. I sam je Papa u svojem govoru rekao da predaja vjerodajnica znači 'povijesni korak' te dodao da su 'odnosi hrvatskog 
naroda s Rimskom Crkvom vrlo davni i da će 'ti odnosi biti još čvršći otkako je Hrvatska opet stekla neovisnost'. Nakon predaje vjerodajnica slijedili su posjeti raznim kongregacijama i papinskim vijećima te kurtoazni posjeti kolegama veleposlanicima. Mislim da bi bilo pošteno i ispravno u ovom trenutku istaknuti da sam vrlo brzo shvatio koliko je pogrešno ono što su govorili neki političari i što se moglo čitati u nekim listovima, naime da su Svetu Stolicu i Papu zanimali samo hrvatski narod i njegova sudbina. Premda je bilo vrlo jasno tko je u tom ratu bio žrtva, a tko agresor, Sveta Stolica 'pokazala je veliku brigu za sve narode Jugoslavije, upućivala molitve za mir u ime svih i izražavala solidarnost za sve žrtve sukoba'. Čim sam se našao u Rimu te poslije, tijekom svojega diplomatskog iskustva, imao sam uvid u razne dokumente iz kojih su jasno vidljivi golemi napori vatikanske diplomacije ulagani $\mathrm{u}$ izbjegavanje nasilja u našoj zemlji i nalaženje rješenja za uspostavu novih odnosa, takvih da osiguravaju prava i legitimne težnje svakog naroda jugoslavenske federacije. Mogao sam iz rečene dokumentacije, a i iz mnogih susreta sa svojim vatikanskim sugovornicima, primijetiti da se u ranoj fazi još navodila mogućnost preobrazbe 'federacije' u 'konfederaciju', ali su 'vojne akcije federalne vojske, okrenute protiv Slovenije i pogotovo protiv Hrvatske, pokopale tu mogućnost' " (Livljanić, 2014, 87-88).

Livljanićev citat važan je i stoga jer argumentirano opovrgava sumnje u nekritičku sklonost Ivana Pavla II. i Svete Stolice Hrvatskoj. Očito je Sveta Stolica u početku držala potrebnim pokušati uspostaviti mir u Jugoslaviji i otvoriti mogućnost dogovornoga rješenja krize, no kada je bilo očito kako to nije moguće i da zajednička država više ne postoji osim "na papiru", započela je svojevrsnu "kampanju”, kako je to napisao američki veleposlanik Melady, za priznanje Hrvatske i Slovenije.

\section{Zaključak}

Kada govorimo o međunarodnom priznanju Hrvatske od Svete Stolice, posebice važne uloge imali su kardinali Tauran i Sodano, a uloga je pape Ivana Pavla II. ne samo nezaobilazna, nego presudna. Sveti Otac volio je Hrvatsku i Hrvate. Kao čovjek iz "Bijele Hrvatske" imao je spoznaje o hrvatskoj povijesti i o načinu kako je ona dospjela u prvu i drugu Jugoslaviju, a kao svećenik i biskup iz komunističke Poljske veoma je dobro znao što je komunizam i što su prošli narodi, posebice vjernici, u zemljama u kojima je vladao. Poznavao je kardinale Šepera i Kuharića te znao ulogu i važnost Crkve u povijesti hrvatskoga naroda. ${ }^{10}$ Stoga je njegovo zauzimanje za hrvatsku neovisnost imalo snažna povijesna i duhovna

10 Povodom jubileja Trinaest stoljeća kršćanstva u Hrvata, tadašnji kardinal Wojtyla u pismu mons. Franji Kuhariću naziva Hrvate i Poljake braćom po vjeri: »Velike svečanosti što ih ove godine slavi Crkva bratskoga hrvatskog naroda pobuđuje žive uspomene i razmišljanja koja Vam želimo prenijeti ovim pismom. [...] Treba naglasiti i veze što sjedinjuju naša dva naroda sa Svetom Stolicom, veze što ih ne mogoše raskinuti sve stoljetne teškoće. U vas kao i u nas sjeme kršćanstva klijalo je polako, i to bez ikakva prolijevanja krvi pogana... [...] Istom hrabrošću i istom vjernošću naše su dvije Crkve podnosile neprijateljska protivljenja i progone koje smo doživljavali kroz 
uporišta. Iako je taktizirao, pazeći da ne razdraži one koji su iz ma kojih razloga bili protiv priznanja Hrvatske, njegova naklonost nije mogla proći nezapaženo. Stoga je njegovo zauzimanje za priznanje Hrvatske izazivalo čuđenje i nekih osoba i struktura u Vatikanu, no on je ostao nepokolebljiv i dosljedan zagovornik i branitelj legitimnih povijesno-političkih prava hrvatskoga naroda, usmjeravajući $\mathrm{k}$ tomu čitavu vatikansku diplomaciju i preko nje međunarodnu zajednicu (Blažević, 1995, 19).

Dakako, uvijek se može postaviti pitanje jesu li Sveta Stolica i papa Ivan Pavao II. osobno trebali i mogli ranijim djelovanjem spriječiti mnoge tragične događaje? Pritom imamo na umu da hrvatsko državno vodstvo u svibnju 1991. još nije moglo s jasnom sigurnošću prepoznati naklonost Svete Stolice prema neovisnosti Hrvatske i odlučnost za djelovanje u tome smjeru, čemu se nadalo i u koje se pouzdavalo. U odgovoru na to pitanje moraju se prije svega uzeti u obzir navedena temeljna načela djelovanja diplomacije Svete Stolice: katolicitet, univerzalni humanizam i neutralnost. U tom smislu može se promatrati i njezinu suzdržanost na početku jugoslavenske krize, budući da je bila riječ o europskom tlu i narodima koji su stoljećima bili njezina briga, kao i radi ekumenskih razloga i vatikanske "istočne politike". S druge strane, Sveta Stolica pokazala je da nije spremna unedogled pasivno čekati rasplet jugoslavenske krize, pogotovo nije bila spremna prihvatiti "svršen čin" na temelju agresivnoga vojnoga djelovanja srpske strane. Spoznavši da ima država koje tvrdokorno žele održati jugoslavenski državni okvir, iako je on tada već bio puki provizorij, čime se išlo na ruku srpskim presizanjima, svojim je djelovanjem za međunarodno priznanje tadašnjih saveznih republika koje to žele "gurala" u istom smjeru države, osobito Europske zajednice, koje su tomu bile sklone. Potičući pak priznanje Hrvatske i Slovenije "u paketu", otupljivala je prigovore onih političara koji su prihvatili ili promicali tezu da se diplomatskim priznanjem Hrvatske želi naštetiti Srbima. Sveta Stolica pokazala je u tim okolnostima veliko umijeće diplomatskoga usmjeravanja i vođenja političkih postupaka.

Nedvojbeno, priznanje Hrvatske od Svete Stolice nadilazi njezino uobičajeno diplomatsko postupanje, ne samo zbog toga što se priznanje u vremenskom slijedu dogodilo među prvima (nakon Islanda i tek osamostaljenih Ukrajine, Estonije i Latvije, čije priznanje međutim nije imalo poticajnu snagu da se i druge države, pogotovo veće, odluče na to) i ne samo zbog njezine aktivne diplomacije u prilog tomu prema trećim državama, nego i stoga što se dogodilo usred rata u korist državi s više od četvrtine okupiranoga ozemlja.

Memoarski zapisi hrvatskih diplomata otkrivaju neke okolnosti i pojedinosti toga puta, koji je za Hrvatsku, ali i za diplomaciju Svete Stolice, a posebice osobno za Ivana Pavla II., bio i više od diplomacije. Iako je Svetoj Stolici i Hrvatskoj pritom bilo jasno, kako je rekao i državni tajnik kardinal Sodano na sastanku veleposlanika KESS-a u Vatikanu 26. studenoga 1991., da se priznanjem državne

cijelu povijest. Te nas sličnosti uzajamno približuju i omogućuju nam da se bolje razumijemo, da se više volimo« (Kocijanić, 1998, 645). 
samostalnosti Hrvatske i Slovenije neće riješiti svi problemi, bio je to Hrvatskoj "ključ u ruke" za vrata izlaska na međunarodnu pozornicu, samim time važno oruđe u budućim političkim i vojnim naporima za oslobođenje i državno-pravnu reintegraciju okupiranih teritorija te za uključivanje Hrvatske u međunarodne organizacije, uza sve ono što se može dublje razmatrati u duhu filozofije i teologije Povijesti, a što nadilazi okvir i cilj ovoga rada.

\section{Literatura}

Blažević, Velimir (ur.) (1995). Služenje miru: Ivan Pavao II. i Sveta Stolica za mir u Hrvatskoj i Bosni i Hercegovini (1991-1995). Zagreb: Kršćanska sadašnjost.

Čečuk, Branimir (2007). Prvo priznanje hrvatske države i međunarodnopravni subjektivitet Svete Stolice. Hrvatska i komparativna javna uprava, 4, 971-994.

Einaudi, Giulio (2003). Dragocjeno služenje Crkvi. Zagreb: Glas Koncila.

Eterović, Nikola (2019). Sveta Stolica i Hrvatska: Priznanje, ugovori, suradnja. Zagreb: Kršćanska sadašnjost.

Fuček, Ivan (1994). Vjerom pobijedimo pustoš u srcima. List mladih MI, 1-2; prilog Zbor, IV, 10(28), 8-9.

Granić, Mate (2019). Diplomatska oluja. Zagreb: Večernji list.

Gregurić, Franjo (1998). Vlada demokratskog jedinstva Hrvatske. Zagreb: Naklada Zadro.

Holjevac-Tuković, Ana; Holjevac, Robert (2019). The Role of the Holy See and Pope John Paul II in the International Recognition of the Republic of Croatia. Bogoslovska smotra, 1, 57-84.

Kocijanić, Juraj (1998). Pape i hrvatski narod. Zagreb: Hrvatski populacijski pokret.

Livljanić, Ive (2017). Od Svetog Grgura do Svetog Petra. Zagreb: Hrvatski institut za povijest.

Maštruko, Ivica (2012). Sveta Stolica A. D. 1991.: Ambasador zemlje koje nema. Zagreb: Novi Liber.

Melady, Thomas Patrick (1997). Veleposlanikova priča. Zagreb: Hrvatska sveučilišna naklada.

Miščin, Daniel (2006). Temelji diplomacije Svete Stolice. Zagreb: Filozofski fakultet Družbe Isusove.

Mlivončić, Ivica (1993). Pape i Hrvati. Zagreb: AGM.

Ostojić, Stevo (1998). Vaticano 1991, la vera storia della lobby Croata. Limes: Rivista Italiana di geopolitica. URL: https://www.limesonline.com/cartaceo/vaticano-1991la-vera-storia-della-lobby-croata (20.11.2020.)

Petrač, Božidar (ur.) (2014). Sveta Stolica i Republika Hrvatska: Dvadeset godina diplomatskih odnosa (1992.-2012.). Zagreb: Alfa.

Petrač, Božidar; Šanjek, Franjo (ur.) (1995). Ivan Pavao II. i Hrvati. Zagreb: Alfa.

Rudolf, Davorin (1991). Rat koji nismo htjeli: Hrvatska 1991. Zagreb: Nakladni zavod Globus.

Valente, Gianni (2011). Vaticano e Kosovo, una spinosa questione diplomatica. Vatican insider. URL https://www.lastampa.it/vatican-insider/it/2011/09/15/news/vaticano-ekosovo-una-spinosa-questione-diplomatica-1.36930602 (21.11.2020.) 
Recognition of the Republic of Croatia by the Holy See in Croatian Memoiristics

On the 30th anniversary of the international recognition of the Republic of Croatia Hrvoje Lončarević*

\section{Summary}

After the Declaration of Independence by the Republic of Croatia on June 25, 1991, which entered into force by a decision of the Croatian Parliament on October 8, 1991, Croatian diplomacy sought to achieve international recognition of the Republic of Croatia as soon as possible. She was supported greatly in this process by the diplomacy of the Holy See, which was guided by the principles of its diplomatic activity - but also by the historically conditioned favour found by the Croats with Pope John Paul II - and very actively encouraged the international recognition process of the Republic of Croatia, as well as the Republic of Slovenia. This article presents some of the most important events during this process, seen from the perspective of Croatian memoiristics. After the introductory section, which recalls the long history of relations between Croats and the Holy See and the main features and goals of the diplomacy of the Holy See, the central section presents the process of the international recognition of Croatia by the Holy See and the establishment of diplomatic relations, with special reference to the testimonies of the last Yugoslav ambassador to the Holy See, Ivica Maštruko, and the first ambassador of the Republic of Croatia, Ivo Livljanić. The author concludes that the recognition of the Republic of Croatia by the Holy See on January 13, 1992, two days prior to recognition by the states of the European Community, sets a precedent in the history of its diplomacy. The Holy See - though we must not neglect the great role of Pope John Paul II in the circumstances of the denouement of the Yugoslav crisis - demonstrated great skill in diplomatic direction and management of political processes and made a key contribution to the international recognition of the Republic of Croatia.

Key words: Holy See; Republic of Croatia; recognition; diplomacy; memoirs

* Hrvoje Lončarević, mag. kroat., mag. comm., Central State Office for the Development of the Digital Society. Address: Ul. Ivana Lučića 8, 10000 Zagreb, Croatia. E-mail: hloncarevic@gmail.com 